\title{
Landowners' perceptions of risk in grassland management: woody plant encroachment and prescribed fire
}

\author{
Ryan N. Harr $^{1,2}$ Lois Wright Morton $^{2}$, Shannon R. Rusk ${ }^{2}, \underline{\text { David M. Engle }}^{3}$, $\underline{\text { James R. Miller }}^{4}$ and Diane Debinski $^{2}$
}

\begin{abstract}
Ecologists recognize that fire and herbivory are essential to maintaining habitat quality in grassland ecosystems. Prescribed fire and grazing are typically used on public reserves to increase biodiversity, improve grassland productivity, and control encroachment of woody plants. However, these tools, particularly prescribed fire, have not been widely adopted by private landowners. Fire suppression and prescribed fire are strategies that present competing risks to owners who make management decisions. We explore landowner perceptions of risk associated with (1) eastern redcedar (Juniperus virginiana) encroachment, and (2) the use of prescribed fire to control woody species in the Grand River Grasslands of Iowa and Missouri, USA. We found that although mapping data of eastern redcedar in this region showed substantial encroachment over the past three decades, concept mapping of landowner beliefs and in-person interviews of local community leaders revealed that perceived risks associated with prescribed fire often outweighed those associated with loss of forage and grassland habitats.
\end{abstract}

Key Words: concept mapping; eastern redcedar; fire suppression; grassland management; landowner perception; prescribed fire; private landowners; risk perception; tallgrass prairie

\section{INTRODUCTION}

North America's midcontinent grasslands were converted to agricultural row crop production in the nineteenth century. Some landscapes reverted to grassland following the drought of the Dust Bowl era (1930s) and are now managed for livestock grazing (Samson et al. 2004). Today these grasslands represent one of the best opportunities to provide habitat for grassland-dependent wildlife and to preserve ecological services on working agricultural lands.

While livestock grazing is commonplace on North American grasslands, prescribed fire has substantively less acceptance. Fire suppression and exclusion, a European cultural norm, were adopted in North American ecosystems (Pyne 1982). Concerns about economic losses from fire and fire suppression occurred concurrently with increasing population density and growth of industrial economies (Guyette et al. 2002). Although the application of fire was once a common agricultural practice, catastrophic fires in the early twentieth century and the rise of the cultural icon Smokey the Bear in the United States reinforced the public belief that fire represents a risk to society and the natural environment (Little 1993).

As scientists have learned more about grassland ecosystems, there is strong evidence that the suppression of fire has led to increases in woody plants and a decrease in grasses and forbs (Heisler et al. 2004, Ansley and Castellano 2006, DeSantis et al. 2011). Fire regimes have influenced grassland evolution for millennia; without it, the encroachment of woody plants creates a different risk-loss of grassland forages for livestock producers and threatens the healthy functioning of grasslands (Gottfried et al. 2009, Bowman et al. 2011). Eastern redcedar (Juniperus virginiana), a hardy, drought-tolerant species, is native to the eastern two-thirds of the continental United States and southeastern provinces of Canada. In the absence of periodic fire, eastern redcedar rapidly colonizes through prolific seed rain, spread of seeds by frugivorous wildlife (Horncastle et al. 2004), and rapid growth after seedling establishment (Engle and Kulbeth 1992). By the mid twentieth century, eastern redcedar was recognized as potentially problematic on grazing lands of the Ozark Plateau (e.g., Martin and Crosby 1955). In more recent times, eastern redcedar expansion has converted vast expanses of Oklahoma and Kansas from open prairie rangelands to closed canopy woodlands (Briggs et al. 2002a, Engle et al. 2008). The ecological consequences of this conversion can be profound, including radical changes in grassland bird and small mammal communities and altered soil chemical and hydrologic properties (Chapman et al. 2004, Coppedge et al. 2004, Pierce and Reich 2010, Alford et al. 2012). Furthermore, economic loss to agricultural producers is manifested in substantially reduced forage production (Ortman et al. 1998).

Much of the research on the use of fire in support of diverse habitats and ecosystem resilience has occurred on publicly owned or not-for-profit reserved lands (e.g., Fuhlendorf et al. 2006, Munyati et al. 2011, Collins and Calabrese 2012, Russell-Smith et al. 2012). Private landowners managing forage resources have traditionally applied costly mechanical treatments and herbicides to control woody species, with limited effectiveness (Bernardo and Engle 1990). Although ecologists understand that fire is an effective means of controlling woody vegetation and promoting herbaceous growth, it is underutilized owing to private landowner concerns over liability, and due to lack of training, proper equipment, and ability to manage fires effectively (Kreuter et al. 2008, Jarrett et al. 2009, Morton et al. 2010). There is a need to extend what has been learned on reserves to private lands to provide larger and more contiguous habitats for biodiversity (Fuhlendorf et al. 2012, Miller et al. 2012). Miller et al. (2012) propose that reserves be used to catalyze adoption of prescribed fire and other grassland conservation practices by private landowners. This Reserves-As-Catalysts model builds grassroots support for prescribed fire by utilizing the group effect, whereby 
a core group of landowners develop relationships around shared goals for managing their lands and together learn the value of prescribed fire.

One deterrent to restoring fire in privately owned landscapes is the perception that fire is unnatural and risky (Yoder 2008, Morton et al. 2010, Bowman et al. 2011). Beliefs about fire's catastrophic potential, sense of controllability, and cultural and social factors influence risk perceptions (Slovic 2009). McDaniels et al. (1995) characterize judgments of ecological risk by impacts on species, human benefits, impact on humans, avoidability, and knowledge of impacts. Risk is inherent to agricultural production on grassland. For example, grassland management west of the $100^{\text {th }}$ meridian in the United States, as in other semi-arid climates around the world, necessitates livestock producers keep an eye towards the following years' forage needs because risk of drought is a constant concern (Holechek et al. 2003). In mesic grasslands, however, higher annual precipitation and deeper, more productive soils reduce, but do not eliminate, production risk involved in grazing grasslands. Rather, these landowners face a different risk, that of woody plant encroachment, in particular eastern redcedar (Juniperus virginiana).

Here we explore landowner perceptions of the risks associated with prescribed fire, encroachment of woody plants (specifically eastern redcedar), and barriers to managing grasslands for both economic livelihoods and ecosystem goals. We focus on agricultural livestock producers and nontraditional, recreational owners in the Grand River Grasslands of Iowa and Missouri, and we document eastern redcedar encroachment in this region. Results from concept mapping and qualitative interviews offer valuable insights as to how key local grassland owners and managers perceive the risks of eastern redcedar encroachment and prescribed fire.

\section{METHODS}

\section{Study area}

The Grand River Grasslands (GRG) encompasses 28,350 ha of rolling, dissected, glacial till plain on the Iowa-Missouri border and includes approximately 180 landowners. This region is unique for its diverse ownerships, with nearly $15 \%$ of the landscape in public and privately owned conservation lands, alongside private working lands dominated by native and non-native grasslands. The region has been identified as the best known opportunity to restore a functional, deep-soil, tallgrass prairie landscape in North America (The Nature Conservancy 2008). Mean annual precipitation for the area is 889 to $1016 \mathrm{~mm}$ (National Climatic Data Center 2008), although precipitation can vary widely between and within years. In recent years, increasing demand for corn and soybeans for biofuel markets and high grain prices converged with expiring 10-to-20-year Conservation Reserve Program contracts, resulting in many grasslands converted to row-crop production (Diffenbaugh et al. 2012). An additional region-wide phenomenon is an increase in nontraditional,typically nonresident and often recreational-landowners who frequently remove lands from production altogether (Duffy and Smith 2008, Morton et al. 2010).

\section{Mapping of eastern redcedar}

To quantify the extent of eastern redcedar encroachment in the Grand River Grasslands, we partnered with the Geospatial Services Laboratory at Saint Mary's University (SMU-GSL) of
Minnesota to conduct an in-depth assessment of eastern redcedar extent at four time steps over the past three decades (1983, 1990, 2002, 2009). For each time period, appropriate satellite imagery was obtained. Eastern redcedar trees were mapped as either individual trees or as polygons in which canopy of several trees comprised $<10 \%$ canopy cover, or as stands delineated within one of three canopy cover categories (10 to $30 \%, 30$ to $70 \%, 70$ to $100 \%$ ). Image analysis using ArcGIS 10.0 (ESRI 2010) began with the most recent time step (2009) and progressed backwards to the earliest time step (1983), assuming that there would be fewer trees in the earlier time steps. Analysts examined each parcel of land within the Grand River Grasslands, delineated locations of individual trees, delineated stand boundaries, determined area of canopy cover of three classes of stands, and differentiated eastern redcedar stands and locations from other tree species. The draft maps were checked for accuracy in conifer species differentiation in the field. For a more detailed description of GIS methodology, see Harr et al. (2012).

\section{Concept mapping}

The Reserves-As-Catalyst model (Miller et al. 2012) offers a framework for understanding how landowners think about fire risks and how to motivate them to adopt prescribed fire as a grassland conservation tool. Following the steps of this model, we identified a core group of key landowners who owned property near public reserves and were leaders having potential influence on other landowners. In December 2009, this nonrandom, invited group of 12 landowners representing the diverse ownership of the Grand River Grasslands (e.g., five traditional cattle grazers, four nonresident landowners, and three recreational owners) was convened to participate in a concept mapping process and to initiate the development of a core grassland group. Some of these individuals owned land adjacent to publicly managed lands; others were identified by local conservation agency staff and the Iowa Cattlemen's Association as local leaders. Concept mapping is an empirical survey method that quantifies and establishes the thematic structure of opinions on a specific topic held by a particular group of people (Cabrera et al. 2008). It utilizes software that integrates brainstorming, multidimensional scaling, scoring, and rating to summarize a group's conceptualization of a given topic (Kane and Trochim 2007, Cabrera et al. 2008).

This group was given the prompt, "One reason conservation practices that improve conditions for wildlife that depend on grassland habitats are not implemented on my land or my neighbors' lands is ...." and was asked to complete the sentence. A facilitator guided the landowners in collectively brainstorming 81 phrases each representing a key idea in response to the prompt. Each participant was then provided a list of the 81 numbered phrases and asked to rate the importance of each item on a Likert scale (range 1 to 5 , where $1=$ not at all important, $2=$ a little important, 3 = moderately important, $4=$ highly important, and $5=$ extremely important). Participants then individually sorted the 81 items (printed on numbered cards) into groups by themes they considered to be related. Once participants had sorted the cards into two or more thematic groups (range 2 to 20), they recorded the statement numbers within each group and assigned the group a title. Responses were mapped using Concept Systems Incorporated (CSI) version 4.0.175 software. Data were entered into concept mapping software which linked each participant (via anonymous ID number) to their rating of each item and then assigned specific items into separate groups (Kane and Trochim 
Fig. 1. Encroachment of eastern redcedar in 1983 (1a), 1990 (1b), 2002 (1c), and 2009 (1d) in the central Grand River Grasslands. Points represent individual trees on the landscape; polygons represent stands of eastern redcedar, with darker shades representing progressively denser stands.
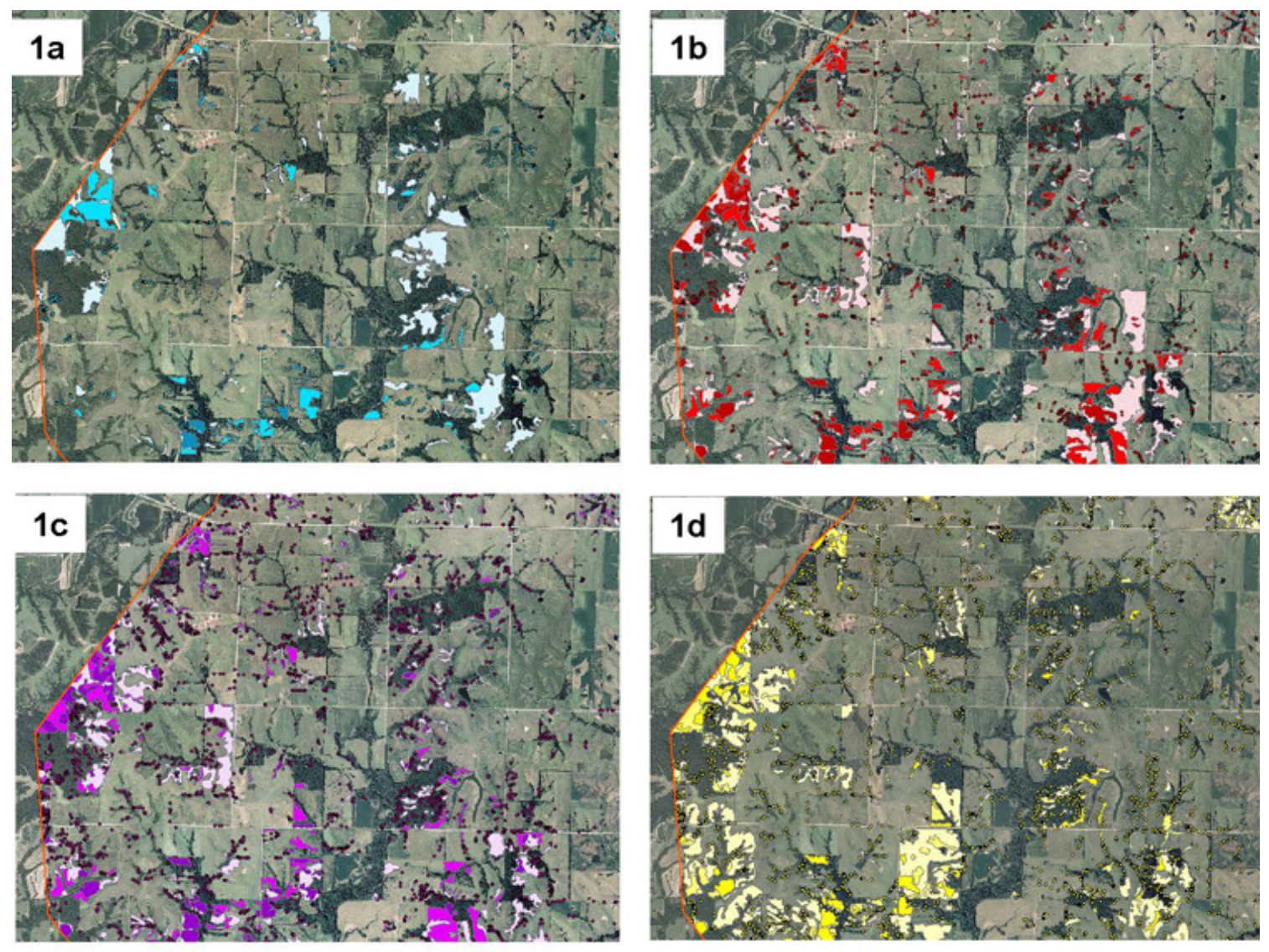

2007). The mean rating for each of the 81 items was analyzed using nonmetric multidimensional scaling to derive eight thematic clusters of related statements. For each cluster, a grand mean and standard deviation (not shown) was computed by totaling means of individual statements within the cluster and dividing by the number of items.

\section{Qualitative interviews}

Individual, semistructured, in-person interviews with ten landowners from the Grand River Grasslands were conducted during the spring of 2011. Interviewees were purposefully selected to represent different categories of landowners (cattle producers, recreational landowners, and owners adjacent to state-owned public lands), with special focus on those with leadership potential who could catalyze neighbors to conservation action (utilizing the Reserves-As-Catalyst model, Miller et al. 2012). Each interviewee was asked questions associated with four conceptual areas: information about their land, land management practices, specific management practices targeting eastern redcedar and other invasive plants, and their vision for the grassland (see Appendix 1 for the interview instrument). Interviews, ranging from 40 to $90 \mathrm{~min}$, were digitally recorded and subsequently transcribed. Transcribed interview text was coded and systematically analyzed by three people to identify key themes and ensure coding reliability. Key themes and quotes from these interviews provided deeper understanding of the clusters identified in the concept mapping analysis. The concept mapping processes and the interview methodologies and instruments were reviewed and approved by Iowa State University's Institutional Review Board.

\section{RESULTS}

\section{Extent of eastern redcedar, 1983 to 2009}

Data derived from satellite imagery of the Grand River Grasslands exhibited an increase in the number of eastern redcedar stands over a 26-year period. Fig. 1 illustrates the change experienced in a localized subset of the grassland and in particular, shows a substantive increase in the number of individual trees spreading across the landscape. In the Iowa portion of the region, the number of delineated eastern redcedar stands (those areas where individual trees coalesced into a canopy) increased from 266 in 1983 to 767 in 2009 (188\% increase) while stand area increased from 349 ha in 1983 to 617.4 ha in 2009 (a $77 \%$ increase). Further, individual trees increased from 997 in 1983 to 9136 in 2009, or over $800 \%$. Expansion of eastern redcedar in the Missouri portion of the region was less pronounced but still notable: although stand area remained constant, the number 
of stands expanded to 550 in 2009 from 389 in 1983 ( $42 \%$ increase) and individual trees increased to 5375 in 2009 from 1251 in 1983, or $330 \%$.

\section{Landowners' concepts of risk: conceptual clusters}

Eight conceptual clusters were constructed from the concept map analysis in response to the statement "One reason conservation practices that improve conditions for wildlife that depend on grassland habitats are not implemented on my land or my neighbors' lands is ... ." These GRG landowner-generated clusters and Likert scale ratings of 81 items offer insights into perceived barriers to the use of prescribed fire as a management tool for grasslands. The eight clusters were ranked in importance based on their grand mean (Fig. 2). Grand means of clusters ranged from 2.46 to 3.06 , with all clusters having some degree of importance (Fig. 3). In many of the clusters the theme of risk was prevalent, with affect or emotional risks associated with fire being prominent in the highest rated groupings. Cluster 1, emotional responses to fire risk, received the greatest number of statements (17) and had the highest grand mean (3.06). Analytical perceptions of risk associated with fire were found in many of the clusters and focused on the practical issues of logistics and management, and they often received ratings of lower importance than for fire risks perceived to harm people or properties. This pattern was observed in the ranking of all 81 individual items without regard to groupings, with emotional affect responses dominating the highest items considered to be barriers to implementing prescribed fire. For example, individual items rated as highly important, included "fire can hurt your neighbors when it gets out of control" (4.25) and "fire can get away really fast" (4.08) in cluster 1. By comparison, items in the lowest ranked cluster (cluster 8, practical obstacles to fire, 2.46) were rated lower -from 3.33 "fire is a problem to existing fences" to 1.58 "fire will stunt my forage growth and hurt the soil". Congruence between the clusters and in-person interviews was striking, with landowners in interviews elaborating their emotional and practical, analytical concerns about fire. Each cluster in Figs. 2 and 3 is discussed below, with quotes and key ideas from landowner interviews used to illustrate and enhance interpretation of the concept map.

\section{Cluster 1: emotional responses to fire risk}

The first cluster, emotional responses to fire risk, had the highest grand mean (3.06). It contained phrases about prescribed fire and eastern redcedar management centered on emotional reactions to the uncertainty and hazards associated with using fire. Many participants used words that conveyed fears for personal safety, liability in case of escape or accident, or the danger fire might pose to neighbors or the community. In this cluster, landowners explicitly stated emotional barriers to landowners using fire: "fire can be dangerous" (3.17) and "fear of fire" (2.42). In addition to giving highly important ratings to concern about fire hurting "neighbors when it gets out of control" (4.25) and the concern that "fire can get away really fast" (4.08), landowners were also highly concerned that "if you have a burn plan" it conveys acceptance of fire and potential liability (3.75) for the prescribed fire. Exposure to liability themes re-occurred throughout this cluster with statements like "fear of fire liability" (3.25), "fire will test the quality of your insurance" (3.25), and "worry about getting sued (liability) with burning if I mess up" (3.00). Several items that rated a little higher than moderately important reflect concern about conducting a fire safely (3.33), the nature of fire _ "creates its own wind, not predictable (3.33) and the need to conduct a fire safely with an experienced crew so it doesn't get away" (3.33). Other items in this cluster relate to affect concerns about community and family perceptions: "Fire department are volunteers, unable to help with prescribed burning" (2.75), "Fire is easily seen, everyone knows about it, very public" (2.17), "Fire is messy, clothes filthy, smelly" (2.00), and "Spouse doesn't like fire or support burning" (1.83).

Fig. 2. Concept map clusters of landowners' reasons for not implementing grassland conservation practices that improve conditions for wildlife.

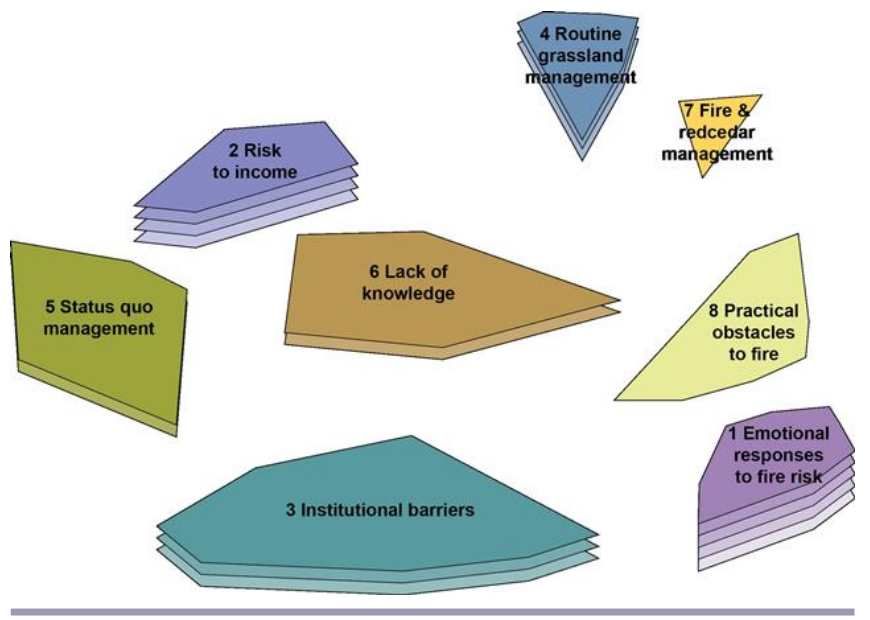

Statements from in-person interviews illustrate and help interpret some of the fears and concerns landowners have that can be barriers to implementing prescribed fire as a grasslands management tool:

.. I think a lot of older people in the neighborhood have
this fear of fire, although I don't think they're necessarily
actually physically afraid unless the wind is blowing in
their direction. [Interview ID \#05201107]
[I'd be] fine with [fire] it if I could maybe get the fire
department here so I didn't burn the county down.
[Interview ID \#04201105]

Cluster 2: risk to income

The cluster rated second highest, risk to income, was rated moderately important as a barrier to implementing conservation practices such as prescribed fire. The Grand River Grasslands is a working agricultural landscape dominated by grazing lands, so it follows that landowners would be concerned about risk to income in using fire as a management tool. Although only eight items were grouped by landowners in this cluster, half were ranked greater than 3.0 (moderately important). The mostly highly rated item, "I focus on practices that return an income stream" (3.83), well articulates this cluster. Three other statements support the focus on the moderate importance of risk to income, all with 3.08 ratings: "Cattle come first", "I can't afford conservation practices", and "I grow forage for cattle, not for wildlife". The tension between viewing cattle as profitable, and wildlife as not 
Fig. 3. Importance ratings of Grand River Grassland landowners for the statement "One reason conservation practices that improve conditions for wildlife that depend on grassland habitats are not implemented on my land or my neighbors' lands is . . ", where $1=$ not at all important, 2 = a little important, $3=$ moderately important, $4=$ highly important, or $5=$ extremely important. Grand mean in bold.

\begin{tabular}{|c|c|c|c|}
\hline Mean & Cluster and Items & \multirow[b]{3}{*}{ Mean } & \multirow[b]{3}{*}{ Cluster and Items } \\
\hline 3.06 & Cluster 1: Emotional Responses to Fire Risk & & \\
\hline 4.25 & Fire can hurt your neighbors when it gets out of control & & \\
\hline 4.08 & Fire can get away really fast & 2.67 & Cluster 5: Status Quo Management \\
\hline 3.75 & If you have a burn plan accept responsibility for the fire, more liability & \multirow[t]{2}{*}{3.42} & \multirow{2}{*}{$\begin{array}{l}\text { Grassland conservation adds another goal to management, adds } \\
\text { complexity, more management workload and planning }\end{array}$} \\
\hline 3.33 & Fire...have to learn how to conduct safely & & \\
\hline 3.33 & Fire requires an experienced crew to manage so it doesn't get away & 3.33 & Trade off: Cost of cattle for gazing vs. cash rent for row crops for land use \\
\hline 3.33 & Fire creates its own wind, not predictable & 3.25 & Expensive to get conservation practices set up \\
\hline 3.25 & Fear of fire liability & 2.75 & I already graze cattle instead of row cropping \\
\hline 3.25 & Fire will test quality of your insurance & 2.58 & Neighbors don't want to fence cattle \\
\hline 3.17 & Fire can be dangerous & 2.33 & Absentee landowner finds it easier, less complicated to take cash rent \\
\hline 3.17 & Fire a secondary goal to grazing/pasture management & 2.25 & Vehicle damage from increased wildlife \\
\hline 3.00 & Worry about getting sued (liability) with burning if I mess up & 2.17 & Lands are jointly owned by family, new ideas are hard to negotiate \\
\hline 2.92 & Fire is hard, hand labor & \multirow[t]{3}{*}{1.92} & \multirow{3}{*}{$\begin{array}{l}\text { I don't want anymore deer on my land, dammit!! And then I'd have } \\
\text { mountain lions, too! }\end{array}$} \\
\hline 2.75 & Fire dept. are volunteers, unable to help with prescribed burning & & \\
\hline 2.42 & Fear of fire & & \\
\hline 2.17 & Fire is easily seen, everyone knows about it, very public & 2.66 & \multirow{4}{*}{$\begin{array}{l}\text { Cluster 6: Lack of knowledge about Management Practices } \\
\text { If I were to leave enough grass for burning, I'd have to reduce my cow } \\
\text { herd } \\
\text { I spend enough time keeping fences up - I don't need to burn up posts and } \\
\text { ruin my hotwire }\end{array}$} \\
\hline 2.00 & Fire is messy, clothes filthy, smelly & \multirow{2}{*}{3.75} & \\
\hline 1.83 & Spouse doesn't like fire or support burning & & \\
\hline 2.84 & Cluster 2: Risk to Income & 3.17 & \\
\hline 3.83 & I focus on practices that return an income stream & \multirow[t]{2}{*}{2.75} & \multirow{2}{*}{$\begin{array}{l}\text { Time constraints don't allow me to do conservation practices because of } \\
\text { other priorities }\end{array}$} \\
\hline 3.08 & I grow forage for cattle, not for wildlife & & \\
\hline 3.08 & Cattle come first & \multirow[t]{2}{*}{2.58} & \multirow{2}{*}{$\begin{array}{l}\text { If I have more wildlife, I'll have more people from Des Moines wanting to } \\
\text { hunt on my ground, maybe even trespassing }\end{array}$} \\
\hline 3.08 & I can't afford conservation practices & & \\
\hline 2.50 & Grass residue has some value e.g. in combination distillers products & 2.50 & \multirow{2}{*}{$\begin{array}{l}\text { I don't have the knowledge or experience } \\
\text { I don't know what conservation practices prote }\end{array}$} \\
\hline 2.42 & I do a good job for wildlife already; have too many deer and turkey as it is & 2.25 & \\
\hline 2.42 & I'm not interested in improving conditions for wildlife & 2.25 & Don't do fire because your family never did it that way \\
\hline 2.33 & Don't know what kind of conservation practices/management I need to do & 2.00 & $\begin{array}{l}\text { Then DNR will bother me more - or those nature conservancy folks, } \\
\text { wanting to buy my property }\end{array}$ \\
\hline 2.80 & Cluster 3: Institutional Barriers & & \\
\hline 3.17 & Confusion of paperwork between landowner and government agencies & 2.57 & Cluster 7: Fire and Redcedar Management \\
\hline 3.17 & Hassel of approval from government & \multirow[t]{2}{*}{2.83} & Need to get fire around the basal bark collar of tree, otherwise doesn't kill \\
\hline 3.08 & USDA gives no encouragement or incentives for using fire as a & & too big a tree \\
\hline & management tool & 2.58 & \\
\hline 3.00 & Confusion on who can sign off on burn plans and burn preparation & 2.58 & Not sure fire works better than chemical \\
\hline 2.92 & All landowners required to fence by law if neighbors request & 2.50 & What do you do with the tree carcass after fire, it is a problem \\
\hline 2.92 & Figuring out the rules between county and the state is difficult & 2.33 & Hate cedar as much as next guy, but provides cover for ground birds \\
\hline 2.83 & CRP may need burned, but there is no technical support & & \\
\hline 2.75 & The government doesn't offer cost-share assistance for burning & 2.46 & Cluster 8: Practical Obstacles to Fire \\
\hline 2.50 & NRCS will not assist in the formation of the burn plan & 3.33 & Fire is a problem to existing fences \\
\hline 2.25 & Don't do fire because the neighbors don't do it, peer review/pressure & 3.25 & Fire causes a disturbance leaving open to thistles and other weeds \\
\hline 2.25 & I don't want weed commissioner on my back about those "weeds" & 3.00 & Takes time to do the prescribed fire \\
\hline & growing in my pasture & 3.00 & Have to hire crew to burn \\
\hline & & 2.83 & Time to realize benefits of fire - takes several years \\
\hline 2.74 & Cluster 4: Routine Grassland Management & 2.75 & Uncertainty of the goal of fire - to increase wildlife? Which type of wildlife? \\
\hline 3.25 & $\begin{array}{l}\text { Loss of quail when cleared fencerow but cedar trees in the fencerow } \\
\text { are worse problem }\end{array}$ & 2.67 & $\begin{array}{l}\text { I just don't have time to burn or implement other practices, much less the } \\
\text { equipment }\end{array}$ \\
\hline 3.25 & Thistle control is a big problem after fire, as are other noxious weeds & 2.50 & Don't have a circle of neighbors or friends to help burn, gets pretty old to \\
\hline 3.08 & Seed source of cedars currently is extensive & & keep "calling in my chips" \\
\hline 2.83 & Chemical doesn't work very well on cedar & 2.08 & I don't know how to burn \\
\hline 2.83 & Takes time to cut cedar trees & 2.00 & Fire is not a clean way of farming \\
\hline 2.67 & CAT on frozen ground can quickly remove cedar & 1.92 & I'm concerned about the health issues related to producing so much \\
\hline 2.42 & Mechanical removal with Bobcat is quick & & smoke in a fire (myself or people in the community) \\
\hline 2.17 & Birds are what put cedar in fencerow, making more birds will increase & 1.92 & I think it harms wildlife to burn \\
\hline & trees & 1.58 & I have never burned deliberately before \\
\hline 2.17 & A few cedars is fine, only a problem when have too many & 1.58 & Fire will stunt my forage growth and hurt the soil \\
\hline
\end{tabular}

profitable, shows up in statements with ratings of 2.42 (a little important): "I do a good job for wildlife already; have too many deer and turkey as it is", and "I'm not interested in improving conditions for wildlife". The last statement in this cluster, "don't know what kind of conservation practices/management I need to do" (2.33), suggests that a barrier to implementing conservation 
practices is not necessarily due to lack of knowledge about which practices to put in place.

Many of the interviewed landowners relied wholly or partially on their lands for personal family income, and the quote below reflects a common refrain about the risk to income when forage for cattle is burned rather than used to support more cattle in the operation.

$$
\begin{aligned}
& \text {.. we've got to make a living off this. If they're a cow- } \\
& \text { calf operation, grass is money, and burning it up isn't } \\
& \text { going to make you a penny. [Interview ID \#05201106] }
\end{aligned}
$$

Although this quote does not mention the need for habitats that support grassland species of concern to ecologists, the landowner makes very clear that the purpose of the grass is to support the cattle that are the basis for the family livelihood. Taken in conjunction with the concept map statements in this cluster about competition between wildlife and forage for cattle, the evidence suggests that landowners view fire that is used in support of diverse habitats for wildlife as competing with the profitability of raising cattle.

\section{Cluster 3: institutional support}

The cluster ranked third highest (2.80) was associated with the lack of institutional support by government agencies and with the community peer pressure that limits implementation of conservation practices. The two highest rated items in this cluster, both moderately important (3.17), were "confusion of paperwork between landowner and government agencies" and "hassle of approval from government". A number of statements reflected lack of government "encouragement or incentives for using fire as a management tool" (3.08), including "government doesn't offer cost-share assistance for burning” (2.75), and CRP (USDA Conservation Reserve Program contracts for set-aside lands) "may need [to be] burned, but there is no technical support" (2.83). Closely aligned with perceptions of a lack of institutional incentives and support was moderately important confusion about intergovernmental boundaries such as "figuring out the rules between county and the state is difficult" (2.92) and confusion about burn plans, "who can sign off on burn plans and burn preparation" (3.00) and "NRCS [Natural Resources Conservation Service] will not assist in the formation of the burn plan" (2.50). Enforcement of local laws about what can be done on personal property, and peer pressure from neighbors, show up in this cluster with statements like "All landowners required to fence by law if neighbors request" (2.92), "Don't do fire because the neighbors don't do it" (2.25), and "I don't want the weed commissioner on my back about those 'weeds' growing in my pasture" (2.25).

Frustration with the availability of technical assistance in planning and implementing prescribed fire and confusion about paperwork and burn plans, are echoed in landowner comments:

... I encourage people to burn, but having said that there are two problems: one is the physical problem of getting it done, and the second problem is the bureaucracy of getting it done. The bureaucracy problem both with NRCS [Natural Resources Conservation Service] in my case because it's CRP [Conservation Reserve Program land] . . . , and you have to put up with the NRCS and the FSA [Farm Service Agency] offices, and that is never pleasant. Getting cooperation from the volunteer fire department was good the first time and not good the second time. [Interview ID \#05201107]

This quote reflects not only frustration with the federal bureaucracy associated with conducting prescribed fires, but also frustration with the limited cooperation and support from local citizen institutions such as the fire department.

\section{Cluster 4: routine grassland management}

In contrast to the first three clusters, which primarily articulated emotional responses to fire safety, risk to income, and lack of institutional support, the remaining five clusters were more analytical in nature, focusing on practical and logistical barriers associated with land management in general. Cluster 4, routine grassland management (2.74), viewed overall as a little less than moderately important, addressed eastern redcedar management. The highest rated item in this cluster (3.25) focused on the problem of eastern redcedar - "Loss of quail [is a problem] with cleared fencerows but cedar trees in the fencerow are a worse problem" - and iterates a theme from cluster 2 (risk to income) of wildlife being a lower priority. Further, there are observations about wildlife being part of the problem- "Birds are what put cedar in fencerows", and making more birds will only increase the number of trees (2.17). While it is recognized that the seed source of cedars is extensive (3.08), chemical management is not working well (2.83) and some forms of mechanical removal such as cutting take time (2.83). There seems to be some confidence that equipment can easily solve the problem, "Cat [bulldozer] on frozen ground can quickly remove cedar" (2.67). There is also a substantive concern that "thistle control is a big problem after fire, as are other noxious weeds" (3.25), suggesting perceptions that mechanical removal does not have this side-effect.

In interviews, landowners frequently noted the ease of mechanical control or other alternatives for dealing with eastern redcedar encroachment, much as they might with other land management concerns. No landowners made any comments indicating concerns about the high cost or ineffectiveness of using mechanical means to manage eastern redcedar on their lands.

\section{... we try to bush hog our CRP [Conservation Reserve Program land $]$ every two or three years and cut fencerows and chainsaw and that kind of thing. [Interview ID \#02201101] \\ ... I don't want acres of redcedar growing, like we had ten acres of it, and we dozed half of it . . there's no grass under it; there's nothing for the cows. But we left the other half for the deer and turkey. [Interview ID \#04201105]}

Although these are well thought out analytical responses to managing eastern redcedar, the apparent lack of knowledge about the extent of potential problems posed by eastern redcedar encroachment is noteworthy. In the second quote above there is acknowledgement of the threat posed by continued encroachment - namely forage loss. Yet in the same statement, the interviewee notes leaving some eastern redcedar, not realizing the threat of spread posed by remaining trees or that eastern redcedar reduces habitat value for many grassland-dependent wildlife.

\section{Cluster 5: status quo management}

During the landowner brainstorming session, participants made a number of statements best described as a preference for the status quo, reflecting satisfaction with current cattle and forage 
management practices. Cluster 5, status quo management (2.67), had a grand mean slightly lower than routine grassland management (Cluster 4) and included sentiments that grazing as a land use is a conservation practice because it is not row cropping. The highest rated item in the fifth cluster was: "Grassland conservation adds another goal to management, adds complexity, more management workload and planning" (3.42) and it was perceived to be a moderately important barrier. Three other items of moderate importance were: "Trade-off: cost of cattle for grazing versus cash rent for row crops for land use" (3.33), "Expensive to get conservation practices set up" (3.25), and "I already graze cattle instead of row cropping" (2.75). The complications of changing current management were also reflected in statements like: "Absentee landowner finds it easier, less complicated to take cash rent" (2.33), and "Lands are jointly owned by family, new ideas are hard to negotiate" (2.17).

Some of these same sentiments were expressed in the landowner interviews. Further, the role of family in continuing current practices and family reluctance to adopting new practices because of increased management complexity, were interview themes. Two statements typified acceptance of current management practices:

\section{. . . a rule of thumb we always used around here, my dad always taught me to use, was approximately 20 to 25 cow-calf pairs per 80 acres. [Interview ID \#05201106]}

. . . it's kind of just been an on-going practice [stocking rate ], and we've been getting along with a hundred head, so that's just sort of where we're at. [Interview ID \#04201105]

Cluster 6: lack of knowledge about management practices The lack of knowledge about management practices, Cluster 6, (2.66) had a grand mean similar to cluster 5-between a little important and moderately important-and revealed limited landowner experience and knowledge about conservation management tools. Two statements were explicit about this limitation: "I don't have the knowledge or experience" (2.58), and "I don't know what conservation practices protect wildlife habitat" (2.25). The barrier of greatest concern was the relationship between prescribed fire and herd size: "If I were to leave enough grass for burning, I'd have to reduce my cow herd" (3.75). Several items within this cluster included time constraints as a barrier to learning more, "I spend enough time keeping fences up - I don't need to burn up posts and ruin my hotwire" (3.17), and "Time constraints don't allow me to do conservation practices because of other priorities" (2.75). Items in this cluster also revealed concerns that managing for wildlife would draw nonfarm people that might trespass: "If I have more wildlife, I'll have more people from Des Moines wanting to hunt on my ground, maybe even trespassing" (2.58), and "Then DNR [Department of Natural Resources] will bother me more, or those nature conservancy folks, wanting to buy my property" (2.00). In-person interviews elaborated on the lack of knowledge of conservation management and the use of fire:

.. how do they stop their fire? How do you make it burn a certain area? [Do they] use like a four-foot tiller on the back of [a tractor]? [Interview ID \#04201105]
How much redcedar would be okay before you're worried about it? [Interview ID \#05201106]

\section{Cluster 7: fire and eastern redcedar management}

The seventh cluster (2.57), with an overall grand mean between somewhat important and moderately important, consisted of specific concerns about fire and eastern redcedar management. It had the fewest number of statements (five) and focused on aesthetics and practicality of using prescribed fire as a means for controlling encroaching eastern redcedar. For example, the most highly rated items were: "Need to get fire around the basal bark collar of the trees, otherwise it doesn't kill too big a tree" (2.83), "Fire kills the big trees but the skeleton of the tree is still a problem" (2.58), and "What do you do with the tree carcass after fire? It is a problem" (2.50). These statements might lead to the conclusion: "Not sure fire works better than chemical" (2.58). Similarly, interview statements reflected an uncertainty that fire worked any better than mechanical or chemical methods, and that there were still "skeletons" of trees remaining after fire.

\section{. . it didn't seem like it [fire] killed very many trees. I mean, if you're using it to kill trees, I don't think it worked very well, because it goes too fast or something, but the trees don't burn up. [Interview ID \#02201101]}

Interviewees also made statements reflecting a lack of understanding of how prescribed fire is implemented, especially regarding the amount of fuel needed to carry a fire that maintains herbaceous plants and pre-empts encroachment of eastern redcedar and other woody species.

\section{Cluster 8: practical obstacles to fire}

The last cluster, with a grand mean midpoint between moderately important and a little important, represents practical obstacles to fire (2.46); and although considered of lowest importance in comparison to the other clusters, it has 14 statements about practical barriers to implementing fire. These include statements considered of moderate importance: "Fire is a problem to existing fences" (3.33) and "Fire causes a disturbance leaving open to thistles and other weeds" (3.25). Time and labor issues are expressed in this cluster: "It takes time to do the prescribed fire" (3.00), "Have to hire crew to burn" (3), "Time to realize benefits of fire takes several years" (2.83), "I just don't have time to burn or implement other practices, much less the equipment" (2.67), and "Don't have a circle of neighbors or friends to help burn, gets pretty old to keep "calling in my chips"' (2.50). Although cluster 6 also included time concerns, they were centered on conservation practices and priorities, whereas in cluster 8 they are specific to managing with fire. One statement in this cluster well expresses the lack of understanding of the role of fire in the landscape, and thus becomes a practical barrier to using it: "Uncertainty of the goal of fire. To increase wildlife? Which type of wildlife?" (2.75).

Related interviewee concerns also ranged from the time it takes to realize the beneficial impacts of prescribed fire to the idea that it is not a "clean" way of farming.

... [it takes time] just learning how to burn. It's not just as simple as going out and throwing a match into the 
grass, although that's how some of the stuff gets burned around this part of the country. [Interview ID \#04201104]

\begin{abstract}
... I have to do it [burn] when I'm available, and that may or may not be the best weather day to do it. Or you have to do it when your volunteer crew can do it. . for absentee landowners such as myself, it's much, much more difficult to get that accomplished because you're not there when the perfect time to do it is. [Interview ID \#05201107]
\end{abstract}

\section{DISCUSSION}

The mapping of eastern redcedar provided an assessment of encroachment rates in the GRG that are of concern to ecologists and should be of concern to local residents. However, the conceptual mapping of how some GRG landowners think about barriers to conservation practices, specifically fire, elicited a different way of thinking about the risks of eastern redcedar encroachment and the use (or not) of prescribed fire as a conservation practice that would improve grassland habitat for wildlife. The concept mapping methodology reveals two general observations. First, although individual statements ranged from highly important to less than a little important, the grand means of the clusters have a very narrow distribution-from 3.06 (moderately important) to 2.46 (halfway between moderately important and a little important). Thus, in general we conclude that all of these groupings are of some importance to landowners and are barriers at some level to implementing conservation practices that would improve conditions for wildlife. The top two clusters, emotional response to fire risk and risk to income, are the strongest clusters, suggesting that these two areas might be particularly responsive to efforts to address ecological and livelihood concerns in this working landscape. Secondly, although the grand mean offers a way to rank (1-8) among clusters, mapping also provides a grouping of similar concepts to give finer detail within each of the clusters. Statements within clusters have a distinct range distribution, with some barriers considered to be highly important, some moderately important, and others of very little importance. A multipronged intervention might target all eight cluster themes but give priority to higher rated items within clusters and offer additional guidance in structuring public dialogs, educational materials and workshops, and public policies.

For the period 1983 to 2009 in the Grand River Grasslands, eastern redcedar encroachment reflects a pattern of heightened risk similar to that already experienced by neighboring grassland states to the south and west (Engle et al. 2008). Landowners frequently view eastern redcedar as a minor concern until it is too late to manage in a cost-effective fashion. The initial period of colonization by eastern redcedar may give a false sense of a localized, manageable problem with low risk. This perception of localized control in the Grand River Grasslands is evident in our in-person interviews and in an earlier survey of landowners and community leaders in which many respondents acknowledged the presence of eastern redcedar on their properties but considered it a minor concern (Morton et al. 2010).

The results of the landowner interviews and the conceptual map that evolved from the interviews, suggest that the landowners' perceived risk of eastern redcedar encroachment is not yet congruent with the "objective" risk represented by the substantive increase in eastern redcedar across the Grand River Grasslands that we mapped. Further, landowners' emotional responses to the high risk of fire seem to dominate the reasons why prescribed fire is not utilized as a conservation measure. Epstein (1994) notes there is plenty of evidence in everyday life to support the notion that people apprehend reality in two fundamentally different ways: one is intuitive, automatic, natural, nonverbal, narrative, and experiential; and the other is analytical, deliberative, verbal, and rational. Slovic's (2009) research shows that the "affect heuristic" of risk perception is often stronger than the "analytical" component of rational decision making. Our findings support that pattern. Three clusters in the concept map, labeled "emotional responses to fire risk", "risk to income", and "institutional barriers," have the highest grand means (above mean 2.80) and consist of many items that Slovic describes as an "affect" response - an emotional or "gut" reaction as to whether it is good or bad. These three clusters represent responses that provoked judgments focused on personal risk such as injury, property damage, loss of income, and frustration with supporting institutions. The strongest responses were concerns for personal safety, danger to neighbors and property, and community. In contrast, the remaining five clusters consisted of more analytical, matter-of-fact, logical statements and seemed to reflect lower perceived risk: paperwork issues, ease of using heavy equipment for land management, or preference for "doing things the way grandpa did them".

Slovic (2009) elaborates that perceived risk increases as perceptions of loss increase. Thus, perceptions of fire as risky may reflect ingrained cultural concerns that fire is more harmful than beneficial. Concepts of risk mean different things to different people; however, a number of studies find expert judgment of risk is highly correlated with technical assessments (Stern 2000). This is evident in the alarm that scientists and grassland wildlife managers express as they examine rates of widespread eastern redcedar encroachment (e.g., Briggs et al. 2002b). In contrast, landowner assessment of risk may be quite different because landowner judgment is sensitive to factors such as personal experience and intuition that help them to quickly measure risk and determine whether further information or immediate action is needed. The combination of analytical and affect heuristics in estimates of risk are the basis for rational management decisions. Relying on affective evaluations alone as a primary cue to risk can be a barrier to assessing the value of prescribed fire as an appropriate management strategy.

\section{CONCLUSIONS}

Human perception, value assessments, and the mental maps associated with ecological risk are relatively new and emerging areas of research. Fire is known to be one of the most costeffective tools for successfully managing eastern redcedar encroachment and preserving grassland productivity and biodiversity (Bernardo et al. 1988, Briggs et al. 2002a), but perceptions of the risks of fire are not well understood and can be barriers to its use. Wildfire can cause substantial economic disruptions, and lead to loss of life and smoke-related problems (Bowman et al. 2011). Highly visible wildfire disasters and the notion that there is no such thing as a "good" fire have inhibited the development of the modern prescribed burning policy (Pyne 
et al. 1996, Bowman et al. 2011) needed to manage woody encroachment. As a result, society often supports fire suppression but not prescribed fire because it views fire in any form as risky and unnatural (Little 1993). This dichotomy of competing paradigms - fire suppression and prescribed fire-make it difficult to employ fire to manage eastern redcedar, reduce fuel loads, and enhance grassland biodiversity (Guyette, et al. 2002, Bowman et al. 2011).

Changing the cultural belief requires a shift in risk perception by building new images and affect heuristics that connect images of grassland ecosystems to prescribed fire. The personal conception of risk is a socially constructed phenomenon that is inherently subjective. Humans use risk to help understand and cope with dangers and uncertainties in life, i.e., they use it as a survival strategy. All risks are subjective, and assumptions and inputs of risk assessments depend on beliefs and judgments about adverse consequences to objects of value.

Therefore, although landowners may consider eastern redcedar a nuisance (an analytic response), the most cost-effective and ecologically appropriate remedy — prescribed fire-may elicit an emotional response to a more immediate risk that overrides concerns about eastern redcedar encroachment. This is a high barrier for ecologists and technical specialists to overcome. Thus, assuming that landowners are rational decision makers with complete information and understanding of fire is an inadequate model for knowledge transfer and application. This suggests that interventions that encourage the use of prescribed fire on private lands must not just have a scientific basis, but also must build on subjective knowledge and customary practices while addressing personal beliefs and fears. Interventions that lead to shifts in social norms often require early adopters and leaders who are willing to balance emotional and analytic responses in order to develop rational decisions about land management.

One way to counter individual emotional responses to risk is to undertake the development of prescribed fire associations that can provide mutual support among landowners who face peer pressure not to burn, offer learning opportunities about eastern redcedar encroachment and the use of fire, and serve as a mechanism for increased understanding of this practice (Taylor 2005, Weir and Bidwell 2005, Twidwell et al. 2013). Prescribed burn associations help overcome fear and cultural reluctance to the use of fire by providing hands-on experience in terms of helping landowners re-evaluate their risk perceptions and incorporate new knowledge about managing grasslands.

As Slovic (2009) reminds us, "whoever controls the definition of risk, controls the rational solution to the problem at hand. If you define risk one way, then one option will rise to the top as the most cost effective or the safest or the best. If you define it another way ... you will likely get a different ordering of your action solutions". Eastern redcedar presents a real and pressing conservation challenge in the grasslands of the central United States, including the Grand River Grasslands. Active interventions that involve small groups of neighboring landowners learning about their individual properties may offer the best route to raising awareness of the threats posed by eastern redcedar. Peer-to-peer learning utilizes the experiential, intuitive knowledge of landowners. It can be most effective when coupled with local scientific and technical support that offers new knowledge and tools for evaluating and addressing the competing risks (Weber 2000, Morton and Padgitt 2005).

Responses to this article can be read online at: http://www.ecologyandsociety.org/issues/responses. $\mathrm{php} / 6404$

\section{Acknowledgments:}

Partial funding for this project was provided through the Iowa State Wildlife Grants program (grant $S W G-C \# U-2-R-1$ ) in cooperation with the U.S. Fish and Wildlife Service, Wildlife and Sport Fish Restoration Program; the Leopold Center for Sustainable Agriculture located at Iowa State University; and the Oklahoma Agricultural Experiment Station. Research was conducted under Iowa State University's Institutional Review Board approval \#09-426. We thank two anonymous people for their reviews, and $R$. Christoffel for an additional review.

\section{LITERATURE CITED}

Alford, A. L., E. C. Hellgren, R. Limb, and D. M. Engle. 2012. Experimental tree removal in tallgrass prairie: variable responses of flora and fauna along a woody cover gradient. Ecological Applications 22:947-958. http://dx.doi.org/10.1890/10-1288.1

Ansley, R. J., and M. J. Castellano. 2006. Strategies for savanna restoration in the southern Great Plains: effects of fire and herbicides. Restoration Ecology 14:420-428. http://dx.doi. org/10.1111/j.1526-100X.2006.00150.x

Bernardo, D. L., and D. M. Engle. 1990. The effect of manager risk attitudes on range improvement decisions. Journal of Range Management 43:242-249. http://dx.doi.org/10.2307/3898682

Bernardo, D. L., D. M. Engle, and F. T. McCollum. 1988. An economic assessment of risk and returns from prescribed burning on tallgrass prairie. Journal of Range Management 41:178-183. http://dx.doi.org/10.2307/3898959

Bowman, D. M. J. S., J. Balch, P. Artaxo, W. J. Bond, M. A. Cochrane, C. M. D'Antonio, R. DeFries, F. H. Johnston, J. E. Keeley, M. A. Krawchuck, C. A. Kull, M. Mack, M. A. Moritz, S. Pyne, C. I. Roos, A. C. Scott, N. S. Sodhi, and T. W. Swetnam. 2011. The human dimensions of fire regimes on earth. Journal of Biogeography 38:2223-2236. http://dx.doi.org/10.1111/ j.1365-2699.2011.02595.X

Briggs, J. M., G. A. Hoch, and L. C. Johnson. 2002a. Assessing the rate, mechanisms, and consequences of the conversion of the tallgrass prairie to Juniperus virginiana forest. Ecosystems 5:578-586.

Briggs, J. M., A. K. Knapp, and B. L. Brock. 2002b. Expansion of woody plants in a tallgrass prairie: a fifteen-year study of fire and fire-grazing interactions. American Midland Naturalist 147:287-294.

Cabrera, D., J. T. Mandel, J. P. Andras, and M. L. Nydam. 2008. What is the crisis? Defining and prioritizing the world's most pressing problems. Frontiers in Ecology and the Environment 6:469-475. http://dx.doi.org/10.1890/070185 
Chapman, R. N., D. M. Engle, R. E. Masters, and D. E. Leslie. 2004. Tree invasion constrains the influence of herbaceous structure in grassland bird habitats. Ecoscience 11:55-63.

Collins, S. L., and L. B. Calabrese. 2012. Effects of fire, grazing, and topographic variation on vegetation structure in tallgrass prairie. Journal of Vegetation Science 23:563-575. http://dx.doi. org/10.1111/j.1654-1103.2011.01369.x

Coppedge, B. R., D. M. Engle, R. E. Masters, and M. S. Gregory 2004. Predicting juniper encroachment on CRP effects on avian population dynamics in southern mixed-grass prairie, USA. Biological Conservation 115:431-441. http://dx.doi.org/10.1016/ $\underline{\text { S0006-3207(03)00160-5 }}$

DeSantis, R. D., S. W. Hallgren, and D. W. Stahle. 2011. Drought and fire suppression lead to rapid forest composition change in a forest-prairie ecotone. Forest Ecology and Management 261:1833-1840. http://dx.doi.org/10.1016/j.foreco.2011.02.006

Diffenbaugh, N. S., T. W. Hertel, M. Scherer, and M. Verma. 2012. Response of corn markets to climate volatility under alternative energy futures. Nature Climate Change 2:514-518.

Duffy, M. D., and D. Smith. 2008. Farmland ownership and tenure in Iowa, 2007. Publication PM 1983 revised. University Extension, Iowa State University, Ames, Iowa, USA.

ESRI. 2010. ArcGIS: Release 10. Environmental Systems Research Institute, Redlands, California, USA.

Engle, D. M., B. R. Coppedge, and S. D. Fuhlendorf. 2008. From the dust bowl to the green glacier: human activity and environmental change in Great Plains grasslands. Pages 253-271 in O. Van Auken, editor. Western North American Juniperus Communities. Springer, New York, New York, USA. http://dx. doi.org/10.1007/978-0-387-34003-6 14

Engle, D. M., and J. D. Kulbeth. 1992. Growth dynamics of eastern redcedar at three locations in Oklahoma. Journal of Range Management 45:301-305. http://dx.doi.org/10.2307/4002982

Epstein, S. 1994. Integration of the cognitive and psychodynamic unconscious. American Psychologist 49:709-724. http://dx.doi. org/10.1037/0003-066X.49.8.709

Fuhlendorf, S. D., D. M. Engle, R. D. Elmore, R. F. Lamb, and T. G. Bidwell. 2012. Conservation of pattern and process: developing an alternative paradigm of rangeland management. Rangeland Ecology and Management 65: 579-589. http://dx.doi. org/10.2111/REM-D-11-00109.1

Fuhlendorf, S. D., W. C. Harrell, D. M. Engle, R. G. Hamilton, C. A. Davis, and D. M. Leslie. 2006. Should heterogeneity be the basis for conservation? Grassland bird response to fire and grazing. Ecological Applications 16:1706-1716. http://dx.doi. org/10.1890/1051-0761(2006)016[1706:SHBTBF]2.0.CO;2

Gottfried, G. J., L. S. Allen, P. L. Warren, B. McDonald, R. J. Bemis, and C. B. Edminster. 2009. Private-public collaboration to reintroduce fire into the changing ecosystems of the southwestern borderlands region. Fire Ecology 5:85-99. http://dx. doi.org/10.4996/fireecology.0501085

Guyette, R. P., R. M. Muzika, and D. C. Dey. 2002. Dynamics of an anthropogenic fire regime. Ecosystems 5:472-486.
Harr, R.N., J. R. Miller, and D. M. Engle. 2012. Quantifying eastern red cedar (Juniperus virginiana) in southern Iowa: a starting point for conversations with landowners about threats to grassland resilience. Leopold Center for Sustainable Agriculture, Iowa State University, Ames, Iowa, USA.

Heisler, J. L., J. M. Briggs, A. K. Knapp, J. M. Blair, and A. Seery. 2004. Direct and indirect effects of fire on shrub density and aboveground productivity in a mesic grassland. Ecology 85:2245-2257. http://dx.doi.org/10.1890/03-0574

Holechek, J. L., R. D. Pieper, and C. H. Herbel. 2003. Range management principles and practices. Prentice Hall Inc., Upper Saddle River, New Jersey, USA.

Horncastle, V. J., E. C. Hellgren, P. M. Mayer, D. M. Engle, and D. M. Leslie. 2004. Differential consumption of eastern red cedar (Juniperus virginiana) by avian and mammalian guilds: implications for tree invasion. American Midland Naturalist 152:255-267. http://dx.doi.org/10.1674/0003-0031(2004)152[0255: DCOERC]2.0.CO;2

Jarrett, A., G. Jianbang, C. Johnson, and I. A. Munn. 2009. Landowner awareness and adoption of wildfire programs in the southern United States. Journal of Forestry 107:113-118.

Kane, M., and W. M. K. Trochim. 2007. Concept mapping for planning and evaluation. Applied Social Research Methods Series, Volume 50. L. Bickman, and D. J. Rog, editors. Sage Publications, Thousand Oaks, California, USA.

Kreuter, U. P., J. B. Woodard, C. A. Taylor, and W. R. Teague. 2008. Perceptions of Texas landowners regarding fire and its use. Rangeland Ecology and Management 61:456-464. http://dx.doi. org/10.2111/07-144.1

Little, C. 1993. Smokey's revenge. American Forests May/June (24-25):58-60.

Martin, S. C., and J. S. Crosby. 1955. Burning and grazing on a glade range in Missouri. Technical Paper 147. Central States Forest Experiment Station, U.S. Department of Agriculture Forest Service, Columbus, Missouri, USA.

McDaniels, T., L. J. Axelrod, and P. Slovic. 1995. Characterizing perception of risk. Risk Analysis 15:575-588. http://dx.doi. org/10.1111/j.1539-6924.1995.tb00754.x

Miller, J. R., L. W. Morton, D. M. Engle, D. M. Debinski, and R. N. Harr. 2012. Nature reserves as catalysts for landscape change. Frontiers in Ecology and the Environment 10:144-152. http://dx. doi.org/10.1890/100227

Morton, L. W., and S. Padgitt. 2005. Selecting socio-economic metrics for watershed management. Environmental Monitoring and Assessment 103:83-98. http://dx.doi.org/10.1007/s10661-005-6855$\underline{\mathrm{Z}}$

Morton, L. W., E. Regan, D. M. Engle, J. R. Miller, and R. N. Harr. 2010. Perceptions of landowners concerning conservation, grazing, fire, and eastern redcedar management in tallgrass prairie. Rangeland Ecology \& Management 63:645-654. http://dx. doi.org/10.2111/REM-D-09-00041.1

Munyati, C., P. Shaker, and M. G. Phasha. 2011. Using remotely sensed imagery to monitor savanna rangeland deterioration through woody plant proliferation: a case study from communal 
and biodiversity conservation rangeland sites in Mokopane, South Africa. Environmental Monitoring and Assessment 176:293-311. http://dx.doi.org/10.1007/s10661-010-1583-4

National Climatic Data Center. 2008. Annual climatological summary statistics. [online] URL: http://www4.ncdc.noaa.gov/ cgiwin/wwcgi.dll?wwDI StnSrch StnID 20012069\#

Ortmann, J., J. Stubbendieck, R. A. Masters, G. H. Pfeiffer, and T. B. Bragg. 1998. Efficacy and costs of controlling eastern redcedar. Journal of Range Management 51:158-163. http://dx. doi.org/10.2307/4003201

Pierce, A. M., and P. B Reich. 2010. The effects of eastern redcedar (Juniperus virginiana) and invasion on a dry bluff prairie ecosystem. Biological Invasions 12:241-252. http://dx.doi. org/10.1007/s10530-009-9446-Z

Pyne, S. J. 1982. Fire in America: a cultural history of wildland and rural fire. Princeton University Press. Princeton, New Jersey, USA.

Pyne, S. J., P. L. Andrews, and R. D. Laven. 1996. Introduction to wildland fire. Second edition. John Wiley and Sons, New York, New York, USA.

Russell-Smith, J., A. C. Edwards, and O. F. Price. 2012. Simplifying the savanna: the trajectory of fire-sensitive vegetation mosaics in northern Australia. Journal of Biogeography 39:1303-1317. http://dx.doi.org/10.1111/j.1365-2699.2012.02679. $\underline{x}$

Samson, F. B., F. L. Knopf, and W. R. Ostlie. 2004. Great plains ecosystems: past, present and future. Wildlife Society Bulletin 32:6-15. http://dx.doi.org/10.2193/0091-7648(2004)32[6:GPEPPA] 2.0. $\mathrm{CO} ; 2$

Slovic, P. 2009. The perception of risk. Earthscan Publications Limited, Sterling, Virginia, USA.

Stern, P. C. 2000. New environmental theories: toward a coherent theory of environmentally significant behavior. Journal of Social Issues 56:407-424. http://dx.doi.org/10.1111/0022-4537.00175

Taylor, C. A. 2005. Prescribed burning cooperatives: empowering and equipping ranchers to manage rangelands. Society for Range Management 1:18-23.

The Nature Conservancy. 2008. Draft Grand River Grasslands Conservation Action Plan. Saint Louis, Missouri, USA.

Twidwell, D., W. E. Rogers, S. D. Fuhlendor, C. L. Wonkka, D. M. Engle, J. R. Weir, U. P. Kreuter, and C. A. Taylor, Jr. 2013. The rising Great Plains fire campaign: citizens' response to woody plant encroachment. Frontiers in Ecology and the Environment 11 (1):64-71.

Weber, E. P. 2000. A new vanguard for the environment: grassroots ecosystem management as new environmental movement. Society \& Natural Resources 13:237-259. http://dx.doi. org/10.1080/089419200279081

Weir, J. R., and T. G. Bidwell. 2005. Prescribed fire associations. F-2880. Oklahoma Cooperative Extension Service, Division of Agricultural Sciences and Natural Resources, Oklahoma State University, Stillwater, Oklahoma, USA.
Yoder, J. 2008. Liability, regulation, and endogenous risk: the incidence and severity of escaped prescribed fires in the United States. Journal of Law \& Economics 51:297-325. http://dx.doi. org/10.1086/589661 
Appendix 1. In-person interview survey instrument for use with Grand River Grasslands landowners. Use of this instrument governed by Iowa State University's Institutional Review Board approval \#09-426.

\section{LANDOWNER QUESTIONS AND PROMPTS BY INTERVIEW ORDER}

\section{Script}

Thanks for agreeing to talk with me about your land management decisions. Our discussion should take about 45 minutes. Here is our project informed consent document. [Interviewer will read aloud the key components of the document with the interviewee] Do you have any questions? Would you please sign that you have read this document and agreed to this interview? Give me one copy and keep the other for your records. Our conversation will be audio taped and transcribed. If you would like a copy of the transcript, let me know and we will send you a copy.

Here is a copy of the questions I'll be asking today. We can skip any that you do not wish to answer and you may end this interview at any time.

\section{Questions and Prompts}

1. I'd like to begin by asking you a little about your land:

a. How many acres of land do you own, rent or manage?

b. About how much of this is grass? How many of these acres do you graze?

c. How many years have you owned/rented/managed land in this area?

d. How important is it that you derive income from this land?

e. How important is the recreational value of your land to your family and others?

\section{Land Management - cattle operator}

You said you graze about ___ acres.

a. What kind of cattle do you have (prompt: cow-calf, stocker, other)? How many cattle do you have?

b. Describe how you manage grazing on your land and why you manage grazing in this manner?

c. How do you determine your stocking rate (number of animals per area for the grazing season)?

d. To what extent are you concerned about drought forage shortfalls for your cattle? What steps have you taken to assure sufficient forage?

e. How have your land management/grazing practices changed over the years?

(If they have farmed here awhile) - What changes in landscape, wildlife, grazing, or farming have you noticed over the years?

f. What are some management practices you'd like to implement but don't think you have the money, time, skills, or labor support to carry out?

g. Would you be willing to try new land management techniques to increase wildlife species on your land? What would make you increase your interest in managing for wildlife on your land?

2. Land Management - non-cattle operating landowner

a. What are your goals for your land? 
b. What kind of management practices are you using on your land so it meets your goals?

c. What are some management practices you'd like to implement but don't think you have the money, time, skills, or labor support to carry out?

d. Would you be willing to try new land management techniques to increase wildlife on your land?

e. (If the answer to 1b is "no") Have you ever considered grazing? Do you have any interest in grazing your land? How could you be convinced to graze your land for the benefit of wildlife?

\section{Redcedar}

a. Are you familiar with the tree called redcedar?

b Have you noticed a change in the amount of redcedar?

c. Do you consider redcedar an asset on your land? In what way?

d. In your opinion, is red cedar a problem on your lands and/or neighboring lands?

e. How much red cedar is ok before you worry about it?

f. Do you see problems stemming from redcedar?

g. If it is a problem, what are you doing about it?

4. Managing red cedar and other non-native nuisance vegetation

a. Have you ever used controlled fire [other than brush piles] on your land to manage your grassland? If so, how many times (and acres per year) have you used controlled fire?

b. What have been your experiences related to burning as a land management tool?

c. What are your views on prescribed burning?

d. To what extent do you think your neighbors view prescribed burning as acceptable?

\section{Your vision for the grasslands}

a. How important are wildlife to you on your lands?

b. What kinds of wildlife do you like seeing on your land and your neighbors?

c. To what extent do you think this area has the kind of habitat needed to support the kinds of wildlife you like to see?

d. How interested or concerned do you think other landowners in the area are in conserving the grasslands and wildlife that prefer grassland habitat?

e. Who are some of your friends or neighbors that you think share your desire to protect and improve the grasslands? [might give us some leads on additional people to invite]

f. What's your vision for what the grasslands will look like 10 years from now?

\section{Concluding statement}

We have been conducting research in this area for a number of years. We have a new grant this year to extend our data collection on private lands. Would you be interested in participating in this project? [provide details of their options to participate] 